\title{
Quantitative PCR marker genes for endometrial adenocarcinoma
}

\author{
ALEXANDRA C. KÖLBL, LISA-MARIE VICTOR, AMELIE E. BIRK, UDO JESCHKE and ULRICH ANDERGASSEN
}

Department of Obstetrics and Gynecology, Ludwig-Maximilians-University of Munich, D-81377 Munich, Germany

Received January 26, 2016; Accepted May 19, 2016

DOI: $10.3892 / \mathrm{mmr} .2016 .5483$

\begin{abstract}
Endometrial adenocarcinoma is a common malignancy in women worldwide, with formation of remote metastasis occurring following oncological treatment. Circulating tumor cells (CTCs) are regarded to be the origin of haematogenous metastasis formation. The present study aimed to identify suitable marker genes using a quantitative polymerase chain reaction (qPCR) approach to detect CTCs from blood samples of patients with endometrial carcinoma. Therefore, RNA was isolated from endometrial adenocarcinoma cell lines and from healthy endometrial tissue and reverse transcribed to cDNA, which was then used in $\mathrm{qPCR}$ on a number of marker genes. Cytokeratin 19 and claudin 4 were identified as suitable marker genes for CTCs in endometrial adenocarcinoma, due to their high expression in the majority of the cell lines investigated. The expression values of the genes examined varied widely between the different cell lines, which is similar to the variation in the patient samples. Therefore, the necessity for a set of genes for CTC detection and not one single marker gene is demonstrated. qPCR is a fast, cost-efficient and easy to perform technique, which may be used in the detection of CTCs. Investigation of the occurrence of CTCs in cancer patients would aid in the prevention of metastasis and thereby refine treatment.
\end{abstract}

Correspondence to: Dr Udo Jeschke, Department of Obstetrics and Gynecology, Ludwig-Maximilians-University of Munich, 11 Maistrasse, D-81377 Munich, Germany

E-mail: udo.jeschke@med.uni-muenchen.de

Abbreviations: CCNE, cyclin E1; CK19, cytokeratin 19; CLDN-4, claudin-4; CTCs, circulating tumour cells; DEPC, diethylpyrocarbonat; DTCs, disseminated tumour cells; GPER, g-protein coupled estrogen receptor; Her-2, human epithelial growth factor receptor; LHCGR, luteinizing hormone/choriogonadotropin receptor; MAL2, T-cell differentiation protein 2; MGL, mammaglobin; MIG7, migration inducing gene 7; VEGFR, vascular endothelial growth factor receptor

Key words: endometrial adenocarcinoma, quantitative PCR, marker genes, CTC, metastasis, cell lines

\section{Introduction}

Endometrial adenocarcinoma is the fourth most frequent gynecological malignancy in Germany (1), 11,300 women are newly diagnosed with this cancer annually (2). The risk of developing endometrial carcinoma increases with age, and may be augmented by estrogen-based hormonal therapies (3), diabetes mellitus, nulliparity and former carcinomas (4). The most common symptom is sudden bleeding, in peri- and postmenopausal women (5). In contrast to other tumors, preventive screening is often ineffective. A specific diagnosis may only be made by histological tissue examination subsequent to hysteroscopy (6). Therapeutic interventions primarily consist of surgery, followed by radiation therapy (7). Chemotherapy is rarely administered (8). Regardless of medical treatment, in $\sim 25 \%$ of all cases, patients develop remote metastasis (8), resulting in necessary follow-up care (9).

The aim of the present study is to predict the formation of metastasis, in order to prevent the processes associated with metastatic outgrowth. Metastasis develop from single cells that have dissociated from the primary solid tumor, circulate through lymph vessels and the blood stream before settling in different sites of the body, thus allowing for metastatic formation. These single tumor cells are termed circulating tumor cells (CTCs) (10). In cases where CTCs infiltrate the bone marrow, they are able to persist for years without doing any harm and become disseminated tumor cells (DTCs) (11-16). The occurrence of CTCs and DTCs is often an indicator of an unfavorable prognosis for patients $(10,17)$, and therefore are included in international tumor staging systems $(18,19)$.

The detection of DTCs is exhausting and a time-consuming procedure for patients, whereas the detection of CTCs from blood samples is advantageous, as this biomaterial is more easily accessible. One disadvantage in the detection of CTCs from blood samples is that the number of CTCs obtained is small in comparison to the surrounding white blood cells (20); therefore, highly sensitive methods for detection are required. The primary detection system currently available is Cell Search ${ }^{\circledR}$ System, distributed by Veridex LLC (Raritan, NJ, USA), which is approved by the US Food and Drug Administration for metastatic breast cancer. It is based on an immunomagnetic enrichment of tumor cells with fluorescent staining of tumor-specific cell surface epitopes. However, this method is expensive and laborious.

The current study aimed to identify a method for the detection of CTCs using the quantitative polymerase chain reaction (qPCR) method. This is based on the fact that as the 
primary tumor is of epithelial origin and expresses an epithelial gene panel. CTCs may also express these epithelial genes. Therefore, they may be distinguished from blood cells, which are mesenchymal cells, by gene expression. The advantage of this method is that it is more sensitive, less expensive than other methods in the field and may be performed quickly in nearly every laboratory. However, it is challenging to find suitable marker genes for the detection of CTCs, which are able to distinguish between tumor and blood cells (21-23). Therefore, the expression of a set of genes was compared between cells isolated from healthy endometrium and endometrial adenocarcinoma cell lines. To the best of our knowledge, there are only a few studies describing the presence of CTCs in patients with endometrial adenocarcinoma. In particular, a high-risk group of patients with high-grade endometrial adenocarcinomas (24), demonstrated a correlation of the occurrence of CTCs with stemness was demonstrated in a previous study and CTCs were recognized as possible therapeutic targets (25).

The marker genes used in the present study were cyclin E1 (CCNE), cytokeratin 19 (CK19), claudin 4 (CLDN-4), G-protein coupled estrogen receptor (GPER), human epidermal growth factor receptor 2 (Her-2), luteinizing hormone/choriogonadotropin receptor (LHCGR), T-cell differentiation protein 2 (MAL2), mammaglobin (MGL), migration inducing protein 7 (MIG7) and vascular endothelial growth factor receptor 2 (VEGFR2) (Table I). CCNE is often overexpressed in endometrial adenocarcinomas (26) and has been used in qPCR detection of CTCs from blood samples of different malignant entities. CCNE and MAL2 have been identified as useful markers in endometrial carcinoma tissue (27). MIG7 was described as a marker gene, which often predicts poor prognosis in patients with endometrial adenocarcinoma (28). CK19 is a marker of epithelial cells and is also used in the alkaline phosphatase-anti-alkaline phosphatase test, which is routinely used in cancer diagnosis $(29,30)$. CLDN-4 has been recognized as a biomarker in the treatment of patients with endometrial adenocarcinoma (31). MGL is frequently used as a marker gene for breast malignancies; however, it may have an important function in malignant endometrial tissues (32), and was therefore also selected for the set of marker genes to be tested by the present study. The expression of GPER is dysregulated in malignant endometrium and is involved in steroid hormone signaling (33). Her-2 is particularly prevalent in early endometrial tumorigenesis, in coherence with Cox-1 and -2 (34). VEGFR2 is an important factor in metastasis formation and neoangiogenesis, ensuring blood supply in the newly growing tumor mass (35). LHCGR is also associated with tumor staging (36). It is also important for cell proliferation $(37,38)$ and may be correlated with grading of endometrial carcinomas (39).

\section{Materials and methods}

Cell lines and subcultivation. The endometrial adenocarcinoma cell lines AN3CA (HTB-111), HEC-1-A (HTB-112), HEC-1-B (HTB-113), KLE (CRL-1622) and RL-95-2 (CRL-1671) were purchased from American Type Culture Collection (Manassas, VA, USA), Ishikawa (cat. no. 99040201) from European Collection of Authenticated Cell Cultures (Salisbury, UK). All cell lines were established from endometrial carcinoma patients (see Table II) and were cultured in Dulbecco's modified Eagle's medium (DMEM; Biochrom, Ltd., Berlin, Germany), supplemented with 10\% fetal calf serum (FCS; Biochrom, Ltd.) and $1 \%$ penicillin/streptomycin (P/S) (Biochrom, Ltd.), except KLE, as they required DMEM-F12 (Biochrom, Ltd.), $10 \% \mathrm{FCS}$ and $1 \% \mathrm{P} / \mathrm{S}$ as culture medium. Cells were subcultured as indicated by the supplier's protocol.

For RNA isolation, cells were washed with phosphate-buffered saline (Biochrom, Ltd.), and TRIzol LS (Invitrogen; Thermo Fisher Scientific, Inc., Waltham, MA, USA) was added. Cells disrupted by the addition of TRIzol were wiped off the cell culture bottle by a cell scraper (Corning Inc., Corning, NY, USA).

Isolation of endometrial stromal cells from tissue samples. Tissue samples of healthy endometrium were obtained from 10 patients undergoing endometrial examination in scope of fertility and are included in this examination following an unsuspicious pathological result as a negative control group. Patients were informed and had signed consent, following the Declaration of Helsinki (ethical vote LMU 148-12). Samples were maintained in DMEM-F12, $10 \% \mathrm{FCS}$ and $1 \% \mathrm{P} / \mathrm{S}$ at $4^{\circ} \mathrm{C}$ overnight or processed immediately. Extraction of stromal cells was performed as described in Fernandez-Shaw et al (40) and Zhang et al (41). Briefly, tissue was cut in 2-3 mm pieces with a scalpel and incubated with $1 \mathrm{mg} / \mathrm{ml}$ collagenase (Invitrogen; Thermo Fisher Scientific, Inc.) in complete DMEM medium for $2 \mathrm{~h}$ at $37^{\circ} \mathrm{C}$. The suspension was then filtered through $250 \mu \mathrm{m}$ tissue strainers (Thermo Fisher Scientific, Inc.). The liquid phase was placed onto $40 \mu \mathrm{m}$ cell strainers (Falcon; Thermo Fisher Scientific, Inc.). Stromal cells were maintained in the liquid phase and spun down at $300 \mathrm{x} \mathrm{g}$ for $10 \mathrm{~min}$ at $4^{\circ} \mathrm{C}$. The supernatant was discarded, and RNA was isolated from the cell pellet by addition of $1 \mathrm{ml}$ TRIzol LS.

RNA isolation. Cell suspensions were already in TRIzol LS, and $0.2 \mathrm{X}$ volume of chloroform (Merck Millipore, Darmstadt, Germany) was added for RNA isolation. The cell suspension was then vigorously vortexed and centrifuged at $12,000 \mathrm{x} \mathrm{g}$ and $4^{\circ} \mathrm{C}$ for $15 \mathrm{~min}$. The clear liquid phase was carefully aspirated and transferred into a fresh reaction tube. Isopropanol ( $0.5 \mathrm{ml}$; Merck Millipore) was added to each sample, vortexed again and incubated overnight at $-20^{\circ} \mathrm{C}$.

The next day the suspension was centrifuged at $12,000 \mathrm{x} \mathrm{g}$ and $4^{\circ} \mathrm{C}$ for $10 \mathrm{~min}$, the supernatant discarded and the RNA pellet washed by the addition of $1 \mathrm{ml} \mathrm{75 \%} \mathrm{ethanol} \mathrm{(Merck}$ Millipore) and centrifuged at $12,000 \mathrm{x} \mathrm{g}$ and $4^{\circ} \mathrm{C}$ for $10 \mathrm{~min}$. The ethanol was subsequently removed, the pellet air-dried for $15 \mathrm{~min}$ and dissolved in diethylpyrocarbonate-treated water. The concentration and ratio of the isolated RNA was determined photometrically at wavelengths 260 and $280 \mathrm{~nm}$. Only RNA with a ratio of 1.7-1.9 is used for further experiments.

Reverse transcription. A total of $4 \mu \mathrm{g}$ of the isolated RNA in a maximum volume of $6 \mu 1$ were used for reverse transcription. Reverse transcription was performed using SuperScript III First Strand Synthesis Super Mix kit by Invitrogen (Thermo Fisher Scientific, Inc.), according to the manufacturer's protocol. Briefly, $1 \mu \mathrm{l}$ Oligo-dTs and $1 \mu \mathrm{l}$ First Strand buffer were added to the RNA and incubated at $65^{\circ} \mathrm{C}$ for $5 \mathrm{~min}$. Next, 
Table I. Characterization of used marker genes and their respective Taq-Man qPCR primers (Thermo Fisher Scientific, Inc.).

\begin{tabular}{|c|c|c|c|c|}
\hline Gene & $\begin{array}{l}\text { Chromosomal } \\
\text { location }\end{array}$ & Primer cat. no. & Characteriaztion & Function \\
\hline CCNE & $19 q 12$ & Hs_00180319_m1 & Regulator of CDK2 & $\begin{array}{l}\text { Overexpression results in } \\
\text { chromosome instability }\end{array}$ \\
\hline CK19 & $17 \mathrm{q} 21.2$ & Hs_00761767_m1 & $\begin{array}{l}\text { Intermediate filament } \\
\text { protein }\end{array}$ & $\begin{array}{l}\text { Structural integrity of } \\
\text { epithelial cells }\end{array}$ \\
\hline CLDN-4 & $7 q 11.23$ & Hs_00976831_s1 & $\begin{array}{l}\text { Integral membrane } \\
\text { protein }\end{array}$ & $\begin{array}{l}\text { Component of tight } \\
\text { junctions }\end{array}$ \\
\hline GPER & $7 \mathrm{p} 22.3$ & Hs_00173506_m1 & $\begin{array}{l}\text { Binds estrogen, important } \\
\text { for cellular signaling }\end{array}$ & $\begin{array}{l}\text { Some splice variants } \\
\text { are known }\end{array}$ \\
\hline Her-2 & $17 q 12$ & Hs_00170433_m1 & Proto-oncogene & $\begin{array}{l}\text { Overexpression results in development } \\
\text { and progression of aggressive } \\
\text { cancer types }\end{array}$ \\
\hline LHCGR & $2 q 16.3$ & Hs_00174885_m1 & $\begin{array}{l}\text { G-protein coupled } \\
\text { receptor }\end{array}$ & $\begin{array}{l}\text { Male secondary sexual } \\
\text { character development }\end{array}$ \\
\hline MAL2 & $8 q 24$ & Hs_00294541_m1 & $\begin{array}{l}\text { Multispan } \\
\text { transmembrane protein }\end{array}$ & $\begin{array}{l}\text { Involved in polarized } \\
\text { transport }\end{array}$ \\
\hline MGL & $11 q 12.3$ & Hs_00419570_m1 & $\begin{array}{l}\text { Belongs to family } \\
\text { of secretoglobulins }\end{array}$ & $\begin{array}{l}\text { Involved in cell signalling, } \\
\text { immune response and chemotaxis }\end{array}$ \\
\hline MIG7 & $1 \mathrm{p} 22.1$ & Hs_00706258_m1 & $\begin{array}{l}\text { Involved in cell } \\
\text { signalling }\end{array}$ & $\begin{array}{l}\text { Limited to embryonic/fetal } \\
\text { cells and epithelial cancer cells }\end{array}$ \\
\hline VEGFR2 & $4 q 12$ & Hs_00911700_m1 & $\begin{array}{l}\text { Mediator of VEGF-induced } \\
\text { endothelial proliferation, survival, } \\
\text { migration and morphogenesis }\end{array}$ & $\begin{array}{l}\text { Angiogenesis and } \\
\text { vascular development }\end{array}$ \\
\hline
\end{tabular}

CCNE, cyclin E1; CK19, cytokeratin 19; CLDN-4, claudin 4; GPER, G-protein coupled estrogen receptor; Her-2, human epidermal growth factor receptor 2; LHCGR, luteinizing hormone/choriogonadotropin receptor; MAL2, T-cell differentiation protein 2; MGL, mammaglobin; MIG7, migration inducing protein 7; VEGFR2, vascular endothelial growth factor receptor 2; CDK2, cyclin-dependent kinase 2; VEGF, vascular endothelial growth factor.

$10 \mu \mathrm{l} 2 \mathrm{X}$ Reaction Mix and $2 \mu 1$ reverse transcriptase were added and the solution was incubated at $42^{\circ} \mathrm{C}$ for $50 \mathrm{~min}$. Reverse transcriptase was subsequently heat-inactivated by an incubation at $85^{\circ} \mathrm{C}$ for $5 \mathrm{~min}$. The cDNA produced was stored at $-20^{\circ} \mathrm{C}$ until it was used in qPCR.

$q P C R$. For qPCR, $2 \mu \mathrm{l}$ of the respective cDNA sample was pipetted into each well of a 96-well plate (Thermo Fisher Scientific, Inc.). A mastermix for each gene was prepared, for the number of samples, which were analyzed. Therefore, for each reaction, $10 \mu \mathrm{l}$ reaction mix (Thermo Fisher Scientific, Inc.), $7 \mu 1$ water and $1 \mu 1$ of the respective gene-specific probe (Table I) were mixed and $18 \mu \mathrm{l}$ of this mixture was added to the cDNA, giving a total reaction volume of $20 \mu \mathrm{l}$. The plate was sealed and centrifuged at $315 \mathrm{x} g$ for $1 \mathrm{~min}$. and placed in a qPCR machine. The cycles were run in the following scheme: $20 \mathrm{sec}$ at $95^{\circ} \mathrm{C}$ as an initial denaturation, followed by 40 cycles consisting of $3 \mathrm{sec}$ at $95^{\circ} \mathrm{C}$ and $30 \mathrm{sec}$ at $60^{\circ} \mathrm{C}$. Fluorescence was determined at the end of each amplification cycle and the relative quantification values (RQ values) were calculated using SDS-software (version 1.3.1) by the $2^{-\Delta \Delta \mathrm{Cq}}$ method (42). $18 \mathrm{~S}$ was used as an internal reference, and gene expression values of endometrial adenocarcinoma cell lines were set in reference to healthy stromal cells isolated from tissue samples as aforementioned. The reaction assays for each gene and cell line were performed as quadruplicates.

\section{Results}

In order to identify a suitable set of marker genes for CTC-detection from blood samples of patients with endometrial adenocarcinoma, qPCR was performed on mRNA/cDNA obtained from 6 human endometrial adenocarcinoma cell lines (AN3 CA, HEC-1-A, HEC-1-B, Ishikawa, KLE, RL95-2) and from healthy endometrial tissue, with 10 different genes, which were previously described in the literature as qPCR marker genes or were associated with endometrial carcinoma and metastasis formation.

RQ values of $>1$ were deemed to be a indicator of upregulation of gene expression in comparison to the expression levels of the same gene in the reference tissue (healthy endometrium). RQ values $<1$ indicated that the gene was expressed at a lower level compared with the control sample.

The present study found low RQ values for LHCGR, VEGFR2 and MGL, which in all cell lines have RQ values $<1$, with the exception of VEGFR2 in KLE-cells, where the RQ 
Table II. Endometrial adenocarcinoma cell lines.

\begin{tabular}{|c|c|c|c|c|c|c|c|}
\hline $\begin{array}{l}\text { First } \\
\text { author, year }\end{array}$ & Cell line & $\begin{array}{l}\text { Tumour } \\
\text { type }\end{array}$ & $\begin{array}{c}\text { Donor } \\
\text { age (years) }\end{array}$ & $\begin{array}{l}\text { Donor } \\
\text { ethnicity }\end{array}$ & Depositor & $\begin{array}{l}\text { Cell line } \\
\text { characteristics }\end{array}$ & Refs \\
\hline Dawe, 1964 & AN3CA & Adenocarcinoma & 55 & Caucasian & CJ Dawe & $\begin{array}{l}\text { Isolated from metastatic } \\
\text { lesion in lymph nodes }\end{array}$ & (43) \\
\hline Kuramoto, 1972 & HEC-1-A & Adenocarcinoma & 71 & Caucasian & H Kuramoto & $\begin{array}{l}\text { Cells from well differentiated } \\
\text { adenocarcinoma (grade II), } \\
\text { expresses platelet activated } \\
\text { growth factor and c-fos, } \\
\text { tumourigenic in nude mice }\end{array}$ & (44) \\
\hline Kuramoto, 1972 & HEC-1-B & Adenocarcinoma & 71 & Caucasian & H Kuramoto & $\begin{array}{l}\text { Substrain of HEC-1-A, more } \\
\text { flattened growth, tumourigenic } \\
\text { in nude mice, diploid to tetraploid }\end{array}$ & (44) \\
\hline Lessey, 1996 & Ishikawa & Adenocarcinoma & 39 & Asian & A Taylor & $\begin{array}{l}\text { Induces cancer in nude mice, } \\
\text { expresses ER and PR }\end{array}$ & $(45)$ \\
\hline Hendricks, 1997 & KLE & Adenocarcinoma & 64 & Caucasian & GR Richardson & $\begin{array}{l}\text { Tumourigenic in nude mice, cells } \\
\text { have microvilli and junctional } \\
\text { complexes, no formation } \\
\text { of glands observed }\end{array}$ & $(46)$ \\
\hline Way, 1983 & RL-95-2 & Carcinoma & 65 & Caucasian & DL Way & $\begin{array}{l}\text { Expresses ER, possesses } \\
\alpha \text {-keratin, cells have junctional } \\
\text { complexes and surface microvilli }\end{array}$ & $(47)$ \\
\hline
\end{tabular}

value is 4.742. In RL95-2 cells, LHCGR had a very low expression level, and even after 40 cycles of PCR no PCR-product was fluorescently detected, resulting in a not detected (nd) RQ value. The remaining seven genes tested via qPCR had different expression levels in the various cell lines tested. High expression levels were observed for CLDN-4 and CK19, especially in RL95-2 cells (317.51 and 501.911, respectively). This was also evident in the remaining five cell lines; however, not to the same extent. For Her-2, CCNE and MAL2 intermediate expression levels were found. GPER and MIG7 were upregulated in comparison with healthy tissues in the majority of the cell lines investigated, with exception of MIG7 in RL95-2 cells (0.897) and GPER in Ishikawa (0.211) and KLE (nd) (Fig. 1; Table III).

\section{Discussion}

In the present study, markedly different gene expression values were observed between the different genes, and also between the cell lines. The differences observed for one gene among the different cell lines to a certain degree reflects the situation, that would occur when using patient samples. For example, the gene expression levels in the HEC-1-A and HEC-1-B cell lines are similar, possibly due to their common origin. By contrast, the Ishikawa cell line has a different gene expression pattern, which is rather different compared with the remaining cell lines. This could be due to it being the only cell line that was obtained from an Asian patient, whereas the rest were from Caucasian patients; therefore, it is possible that the carcinomas developed in different genetic backgrounds. Furthermore, the donor of the Ishikawa cell line was younger, possibly premenopausal, whereas the donors of the other cell lines were older and presumably postmenopausal, and this may additionally have contributed to the variations in genetic background for tumorigenesis. Therefore, in order to successfully detect CTCs from blood samples of patients with endometrial adenocarcinoma, the primary challenge is to establish a suitable set of marker genes, which would enable the detection of CTCs with a high sensitivity. These results are in accordance with previous findings using breast cancer cell line cells and blood samples from patients with breast cancer for CTC detection (21-23).

CLDN-4 and CK19 were identified to be highly suitable, confirming the recent results of Pan et al (31), which used CLDN-4 as a biomarker for endometrial adenocarcinoma. By contrast, CK19 is an established marker gene and has been used in tumor cell diagnostics routinely $(29,30)$. CK19 is a typical epithelial marker, therefore it is not unusual that it is expressed in CTCs. Furthermore, Her-2 and MAL2 may also be suitable marker genes, with high expression levels in the majority of cell lines investigated in the present study. MAL2 was also previously identified as a marker gene in endometrial adenocarcinoma (27). A previous study has determined that the expression levels of CCNE are upregulated in endometrial adenocarcinoma (26). Additionally, as Her2 also exhibits high expression levels in the majority of the cell lines, and may be easily detected by qPCR, it represent a potential marker gene in patient samples, as it has been previously identified as a marker of early tumorigenesis (34).

LHCGR, VEGFR2 and MGL exhibited a consistently lower expression across the tumor cell lines investigated. However, this does not mean that these genes are not important for tumorigenesis and the formation of remote metastasis. It is possible that the mRNAs of those genes are degraded quickly following protein translation and therefore that their expression may not be determined using qPCR. In order to 
Table III. Relative quantification values for all genes and cell lines examined.

\begin{tabular}{|c|c|c|c|c|c|c|}
\hline & AN3 CA & HEC-1-A & HEC-1-B & Ishikawa & KLE & RL95-2 \\
\hline CCNE & 0.045 & 8.938 & 40.558 & 15.215 & 9.807 & 2.582 \\
\hline CK19 & 2.716 & 3.069 & 40.581 & 3.305 & 45.305 & 501.911 \\
\hline CLDN-4 & 7.063 & 0.345 & 86.115 & 42.771 & 11.693 & 317.510 \\
\hline GPER & 10.682 & 1.002 & 2.345 & 0.211 & nd & 9.547 \\
\hline Her-2 & 10.095 & 68.220 & 59.618 & 4.491 & 78.536 & 5.297 \\
\hline LHCGR & 0.005 & 0.016 & 0.201 & 0.018 & 0.328 & nd \\
\hline MAL2 & 0.003 & 58.343 & 55.510 & 15.292 & 30.297 & 12.726 \\
\hline MGL & 0.015 & 0.010 & 0.003 & 0.008 & 0.005 & 0.011 \\
\hline MIG7 & 4.513 & 4.974 & 8.131 & 1.781 & 7.839 & 0.897 \\
\hline VEGFR2 & 0.002 & 0.003 & 0.003 & 0.010 & 4.742 & $<0.001$ \\
\hline
\end{tabular}

CCNE, cyclin E1; CK19, cytokeratin 19; CLDN-4, Claudin 4; GPER, G-protein coupled estrogen receptor; Her-2, human epidermal growth factor receptor 2; LHCGR, luteinizing hormone/choriogonadotropin receptor; MAL2, T-cell differentiation protein 2; MGL, mammaglobin; MIG7, migration inducing protein 7; VEGFR2, vascular endothelial growth factor receptor 2; nd, not detected.

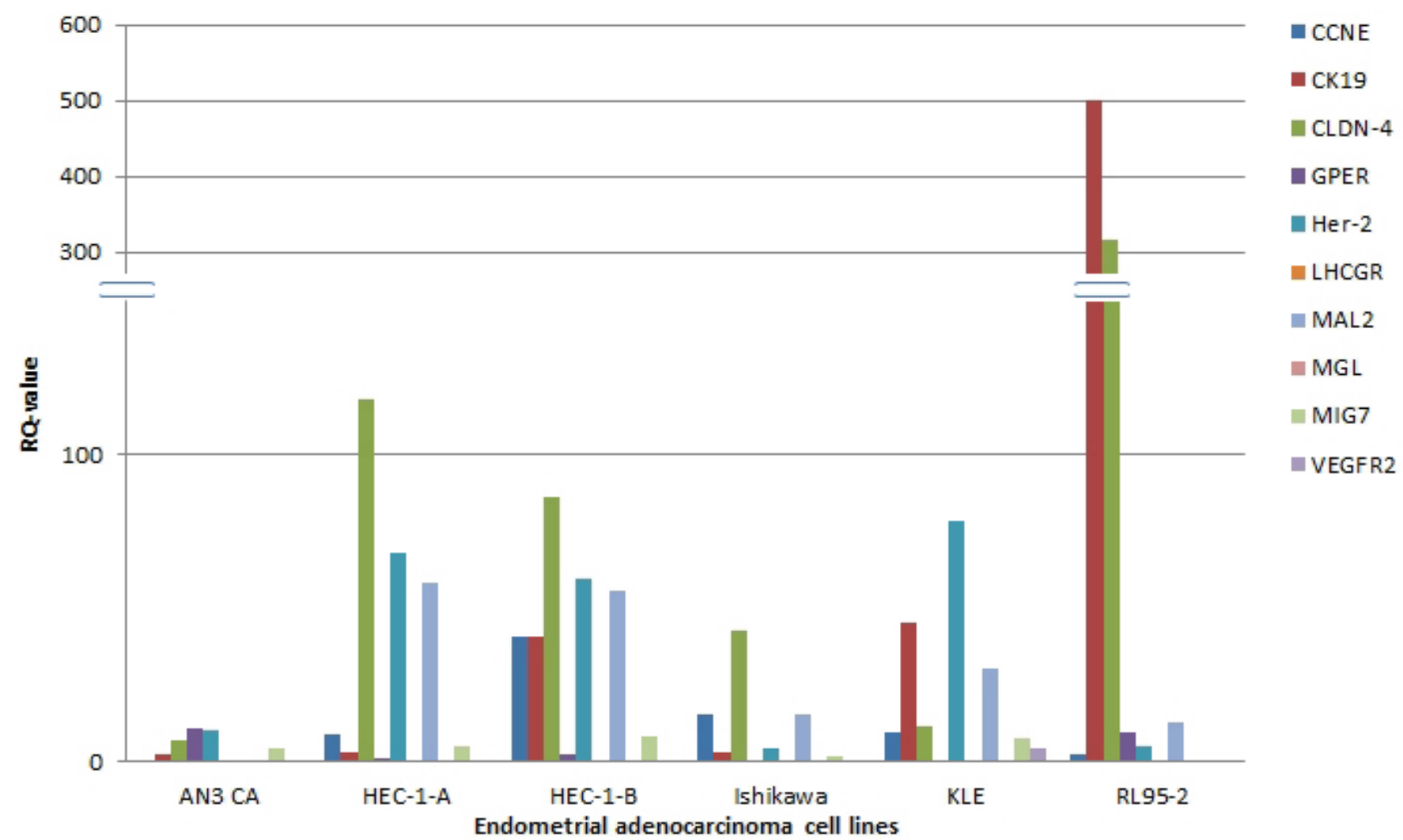

Figure 1. Comparison of the expression of the different genes in various endometrial adenocarcinoma cell lines. CCNE, cyclin E1; CK19, cytokeratin 19; CLDN-4, Claudin 4; GPER, G-protein coupled estrogen receptor; Her-2, human epidermal growth factor receptor 2; LHCGR, luteinizing hormone/choriogonadotropin receptor; MAL2, T-cell differentiation protein 2; MGL, mammaglobin; MIG7, migration inducing protein 7; VEGFR2, vascular endothelial growth factor receptor 2.

overcome this obstacle, a potential approach may be to investigate marker genes with long RNA half-lives, thus increasing the time available for detection.

In conclusion, $\mathrm{qPCR}$ is a potential method for the diagnosis of CTCs in endometrial adenocarcinoma. Therefore, it may aid in the refinement of treatment options, and indicate whether a patient has a particular potential for metastasis, as CTCs are present in the blood stream. The present study indicates a potential set of reliable marker genes which may be used with this methodology, however, further studies are required to confirm and expand upon this. It will be important to clarify whether particular levels of gene expression can be correlated to specific numbers of tumor cells in a blood sample. Therefore standard curves would be required to be generated, using varying quantities of tumor cells diluted in blood samples from healthy individuals, an approach already in use for breast 
cancer (23). A potential limitation of the method is that for particular genes additional methods may be required, in order to clarify their expression, as identified by the present study for LHCGR, MGL and VEGFR2. qPCR is a fast, cost-efficient and easy to perform method, which may be conducted in the majority of laboratories, and may be a useful tool for CTC detection in various types of cancer.

\section{Acknowledgements}

The current study was supported by the Funding Program for Research and Teaching at of LMU Munich and Dr Alexandra Kölbl was supported by the Engelhorn-Foundation for Medical Research.

\section{References}

1. Emons G, Mallmann P; and acting for the Uterus Commission of AGO: Recommendations for the Diagnosis and Treatment of Endometrial Cancer, Update 2013. Geburtshilfe Frauenheilkd 74: 244-247, 2014

2. Husmann G, Kaatsch P, Katalinic A, Bertz J, Haberland J, Kraywinkel K and Wolf U: Cancer in Germany 2005/2006. Incidence and Trends. 7th edition. Robert Koch Institute and Association of Population-based Cancer Registries in Germany, Berlin, 2010.

3. Emons G and Heyl W: Hormonal treatment of endometrial cancer. J Cancer Res Clin Oncol 126: 619-623, 2000.

4. Hecht JL and Mutter GL: Molecular and pathologic aspects of endometrial carcinogenesis. J Clin Oncol 24: 4783-4791, 2006.

5. Moodley M and Roberts C: Clinical pathway for the evaluation of postmenopausal bleeding with an emphasis on endometrial cancer detection. J Obstet Gynaecol 24: 736-741, 2004.

6. Marsden DE and Hacker NF: Optimal management of endometrial hyperplasia. Best Pract Res Clin Obstet Gynaecol 15: 393-405, 2001

7. Tumorzentrum M: Malignome des Corpus Uteri. PD Dr. Christian Dann ecker PMKaPRK (ed). W. Zuckerschwendt Verlag: Munich, Vienna, New York, 2007 (In German).

8. Amant F, Moerman P, Neven P, Timmerman D, Van Limbergen E and Vergote I: Treatment modalities in endometrial cancer. Curr Opin Oncol 19: 479-485, 2007.

9. Beckmann K, Iosifidis P, Shorne L, Gilchrist S and Roder D: Effects of variations in hysterectomy status on population coverage by cervical screening. Aust N Z J Public Health 27: 507-512, 2003

10. Franken B, de Groot MR, Mastboom WJ, Vermes I, van der Palen J, Tibbe AG and Terstappen LW: Circulating tumor cells, disease recurrence and survival in newly diagnosed breast cancer. Breast Cancer Res 14: R133, 2012.

11. Bragado P, Sosa MS, Keely P, Condeelis J and Aguirre-Ghiso JA: Microenvironments dictating tumor cell dormancy. Recent Results Cancer Res 195: 25-39, 2012.

12. Diel IJ, Solomayer EF, Costa SD, Gollan C, Goerner R, Wallwiener D, Kaufmann M and Bastert G: Reduction in new metastases in breast cancer with adjuvant clodronate treatment. N Engl J Med 339: 357-363, 1998.

13. Pantel $\mathrm{K}$ and Woelfle U: Micrometastasis in breast cancer and other solid tumors. J Biol Regul Homeost Agents 18: 120-125, 2004.

14. Riethdorf S and Pantel K: Disseminated tumor cells in bone marrow and circulating tumor cells in blood of breast cancer patients: Current state of detection and characterization. Pathobiology 75: 140-148, 2008.

15. Ring A, Smith IE and Dowsett M: Circulating tumor cells in breast cancer. Lancet Oncol 5: 79-88, 2004.

16. Smerage JB and Hayes DF: The measurement and therapeutic implications of circulating tumor cells in breast cancer. Br J Cancer 94: 8-12, 2006.

17. Graves $\mathrm{H}$ and Czerniecki BJ: Circulating tumor cells in breast cancer patients: An evolving role in patient prognosis and disease progression. Patholog Res Int 2011: 621090, 2011.

18. Hermanek P, Hutter RV, Sobin LH and Wittekind C: International union against cancer. Classification of isolated tumor cells and micrometastasis. Cancer 86: 2668-2673, 1999.
19. Singletary SE, Patel-Parekh L and Bland KI: Treatment trends in early-stage invasive lobular carcinoma: A report from the national cancer data base. Ann Surg 242: 281-289, 2005.

20. Ghossein RA, Carusone L and Bhattacharya S: Molecular detection of micrometastases and circulating tumor cells in melanoma prostatic and breast carcinomas. In Vivo 14: 237-250, 2000.

21. Andergassen U, Hofmann S, Kölbl AC, Schindlbeck C, Neugebauer J, Hutter S, Engelstädter V, Ilmer M, Friese K and Jeschke U: Detection of tumor cell-specific mRNA in the peripheral blood of patients with breast cancer-evaluation of several markers with real-time reverse transcription-PCR. Int J Mol Sci 14: 1093-1104, 2013.

22. Andergassen U, Kölbl AC, Hutter S, Friese K and Jeschke U: Detection of circulating tumor cells from blood of breast cancer patients via RT-qPCR. Cancers (Basel) 5: 1212-1220, 2013.

23. Zebisch M, Kölbl AC, Schindlbeck C, Neugebauer J, Heublein S, Ilmer M, Rack B, Friese K, Jeschke U and Andergassen U: Quantification of breast cancer cells in peripheral blood samples by real-time rt-PCR. Anticancer Res 32: 5387-5391, 2012.

24. Bogani G, Liu MC, Dowdy SC, Cliby WA, Kerr SE, Kalli KR, Kipp BR, Halling KC, Campion MB and Mariani A: Detection of circulating tumor cells in high-risk endometrial cancer. Anticancer Res 35: 683-687, 2015.

25. Alonso-Alconada L, Muinelo-Romay L, Madissoo K, Diaz-Lopez A, Krakstad C, Trovik J, Wik E, Hapangama D, Coenegrachts L, Cano A, et al: Molecular profiling of circulating tumor cells links plasticity to the metastatic process in endometrial cancer. Mol Cancer 13: 223, 2014.

26. Cassia R, Moreno-Bueno G, Rodriguez-Perales S, Hardisson D, Cigudosa JC and Palacios J: Cyclin E gene (CCNE) amplification and hCDC4 mutations in endometrial carcinoma. J Pathol 201: 589-595, 2003.

27. Obermayr E, Sanchez-Cabo F, Tea MK, Singer CF, Krainer M, Fischer MB, Sehouli J, Reinthaller A, Horvat R, Heinze G, et al: Assessment of a six gene panel for the molecular detection of circulating tumor cells in the blood of female cancer patients. BMC Cancer 10: 666, 2010

28. Phillips TM and Lindsey JS: Carcinoma cell-specific Mig-7: A new potential marker for circulating and migrating cancer cells. Oncol Rep 13: 37-44, 2005

29. Kurec AS, Baltrucki L, Mason DY and Davey FR: Use of the APAAP method in the classification and diagnosis of hematologic disorders. Clin Lab Med 8: 223-236, 1988.

30. Noack F, Schmitt M, Bauer J, Helmecke D, Krüger W, Thorban S, Sandherr M, Kuhn W, Graeff H and Harbeck N: A new approach to phenotyping disseminated tumor cells: Methodological advances and clinical implications. Int J Biol Markers 15: 100-104, 2000

31. Pan XY, Li X, Che YC, Li HY, Li X, Zhang Y and Yang X: Overexpression of claudin-4 may be involved in endometrial tumorigenesis. Oncol Lett 5: 1422-1426, 2013.

32. Classen-Linke I, Moss S, Gröting K, Beier HM, Alfer J and Krusche CA: Mammaglobin 1: Not only a breast-specific and tumor-specific marker, but also a hormone-responsive endometrial protein. Histopathology 61: 955-965, 2012.

33. Plante BJ, Lessey BA, Taylor RN, Wang W, Bagchi MK, Yuan L, Scotchie J, Fritz MA and Young SL: G protein-coupled estrogen receptor (GPER) expression in normal and abnormal endometrium. Reprod Sci 19: 684-693, 2012.

34. Sugimoto T, Koizumi T, Sudo T, Yamaguchi S, Kojima A, Kumagai $\mathrm{S}$ and Nishimura R: Correlative expression of cyclooxygenase-1 (Cox-1) and human epidermal growth factor receptor type-2 (Her-2) in endometrial cancer. Kobe J Med Sci 53: 177-187, 2007.

35. Pugh CW and Ratcliffe PJ: Regulation of angiogenesis by hypoxia: Role of the HIF system. Nat Med 9: 677-684, 2003.

36. Arcangeli A, Noci I, Fortunato A and Scarselli GF: The LH/hCG axis in endometrial cancer: A new target in the treatment of recurrent or metastatic disease. Obstet Gynecol Int 2010: pii: 486164, 2010.

37. Davies S, Bax CM, Chatzaki E, Chard T and Iles RK: Regulation of endometrial cancer cell growth by luteinizing hormone (LH) and follicle stimulating hormone (FSH). Br J Cancer 83: 1730-1734, 2000.

38. Pike MC, Peters RK, Cozen W, Probst-Hensch NM, Felix JC, Wan PC and Mack TM: Estrogen-progestin replacement therapy and endometrial cancer. J Natl Cancer Inst 89: $1110-1116,1997$. 
39. Noci I, Pillozzi S, Lastraioli E, Dabizzi S, Giachi M, Borrani E, Wimalasena J, Taddei GL, Scarselli G and Arcangeli A: $\mathrm{hLH} / \mathrm{hCG}$-receptor expression correlates with in vitro invasiveness in human primary endometrial cancer. Gynecol Oncol 111: 496-501, 2008.

40. Fernández-Shaw S, Shorter SC, Naish CE, Barlow DH and Starkey PM: Isolation and purification of human endometrial stromal and glandular cells using immunomagnetic microspheres. Hum Reprod 7: 156-161, 1992.

41. Zhang L, Rees MC and Bicknell R: The isolation and long-term culture of normal human endometrial epithelium and stroma. Expression of mRNAs for angiogenic polypeptides basally and on oestrogen and progesterone challenges. J Cell Sci 108 323-331, 1995.

42. Livak KJ and Schmittgen TD: Analysis of relative gene expression data using real-time quantitative PCR and the 2 (-Delta Delta C (T)) method. Methods 25: 402-408, 2001.
43. Dawe CJ, Banfield WG, Morgan WD, Slatick MS and Curth HO Growth in continuous culture, and in hamsters, of cells from a neoplasm associated with acanthossi nigricans. J Natl Cancer Inst 33: 441-456, 1964.

44. Kuramoto H: Studies of the growth and cytogenetic properties of human endometrial adenocarcinoma in culture and its development into an established line. Acta Obstet Gynaecol Jpn 19: 47-58, 1972.

45. Lessey BA, Ilesanmi AO, Castelbaum AJ, Yuan L, Somkuti SG, Chwalisz K and Satyaswaroop PG: Characterization of the functional progesterone receptor in an endometrial adenocarcinoma cell line (Ishikawa): Progesterone-induced expression of the alpha1 integrin. J Steroid Biochem Mol Biol 59: 31-39, 1996.

46. Hendricks DT, Taylor R, Reed M and Birrer MJ: FHIT gene expression in human ovarian, endometrial, and cervical cancer cell lines. Cancer Res 57: 2112-2115, 1997.

47. Way DL, Grosso DS, Davis JR, Surwit EA and Christian CD: In Vitro 19: 147-158, 1983. 